\title{
Facing the facts
}

French literature after the twentieth century

Ne pas (se) raconter d'histoires. La littérature française après le $\mathrm{XX}^{e}$ siècle

\section{Charlotte Lacoste}

Translator. Beth Varley

\section{(2) OpenEdition \\ Journals}

Electronic version

URL: https://journals.openedition.org/pratiques/10333

DOI: 10.4000/pratiques.10333

ISSN: 2425-2042

\section{Publisher}

Centre de recherche sur les médiations (CREM)

\section{Electronic reference}

Charlotte Lacoste, "Facing the facts", Pratiques [Online], 181-182 | 2019, Online since, connection on

04 September 2021. URL: http://journals.openedition.org/pratiques/10333 ; DOI: https://doi.org/

10.4000/pratiques. 10333

This text was automatically generated on 4 September 2021.

(c) Tous droits réservés 


\title{
Facing the facts
}

\author{
French literature after the twentieth century \\ Ne pas (se) raconter d'histoires. La littérature française après le XXe siècle
}

\author{
Charlotte Lacoste
}

Translation : Beth Varley

\section{Neither a novel nor a narrative/story}

1 The rapid growth of what, following the example of the English-speaking world, ${ }^{1}$ is conventionally referred to as "non-fiction" is one of the most remarkable phenomena of very recent years in the field of French literature. This trend, which was not necessarily predictable on the basis of twentieth-century literary history ${ }^{2}$ and which has been accompanied by the creation of journals, publishing houses and collections of life stories at the grass roots of experience, ${ }^{3}$ accelerated from the 2000 s onwards. ${ }^{4}$ It has been substantially reinforced by the public and/or critical success of works, some of which have already acquired the status of classics, ${ }^{5}$ and following the awarding of the Nobel Prize to Svetlana Alexievich in 2015. ${ }^{6}$ Attempts at charting this trend in order to understand this new continent have already produced a number of more or less exclusive labels, including "documentary narrations" (Ruffel, 2012), "reality literature" (Jablonka, 2014), "factographies" (Zenetti, 2014) or "field literatures" (Viard, 2018). Insofar as the set of all "factual literature" (Genette, 2004) could not be held to constitute a "corpus" as such, these labels circumscribe literary enterprises which diverge according to the works considered. Criticism does however give wide recognition for surveys or investigations (Demanze, 2019b), which appear to have been accepted as constituting the key genre of this new archipelago, inhabited by authors coming frequently from journalism or the humanities and social sciences. Thus it is often said that French non-fiction draws from many influences, mainly from the English-speaking world, ranging from social surveys to documentary cinema, and including investigative journalism (the "pen in the wound" in the style of Albert Londres or immersion journalism as practised by Nelly Bly), New Journalism and the non-fiction novel (of which Truman Capote's In Cold Blood serves as a model). However, 
although the survey (social, historical, geographical, familial or focusing on an event in the news) is currently the most visible genre, it coexists with forms of documentary writing which I would like to show involve different genealogies from that which gave rise to the contemporary genre of the literary survey, which remains fundamentally (and paradoxically) linked to the fictional story (Demanze, 2019a). The high visibility of one genre should not be allowed to obscure other ways of confronting reality, which, though they may be less easily identified because of their debt to other legacies, stand resolutely on the margins of the dramaturgy which characterises the investigative genre, and in so doing represent a break from that tradition.

2 My analysis focuses on works sharing an underlying documentary intention, which do constitute a corpus, I would like to shed light on the approaches of authors practising a form of writing which seeks to reflect reality be as closely as possible and to elaborate and bear witness to facts which, for the sake of accuracy, leads them to neglect not only fiction but also narration. In other words, they must face the facts (and confront us with the facts), in a world which is littered with stories, which are in the process of becoming increasingly virtual, and in which the distinction between true and false has become largely "unessential" (Revault d'Allonnes, 2018, p. 34). The texts we will be looking at here exist upstream of narrative, at the level of the world as it is. Their authors undertake methodical explorations of the world in order to uncover present or past facts and account for them from their point of view. They do this as much to point them out to the eyes and consciences of their contemporaries as to pass them down to posterity, and thus constructing a collective memory which, ideally, would forget nothing and nobody - and in doing so spotlight that which our societies denigrate, deny, repress or sweep under the carpet. Their aim, according to the hypothesis I would like to develop here, is to extend to everyday life what the genre of the personal testimony introduced to literature. This literary genre, which emerged in the wake of the mass murders of the twentieth century, $i$ attempts to objectify the data of personal experience for which everybody is accountable. Everybody, by taking on the role as a witness, can give shape and form to personal experience through a text seeking to document life as it was really lived, discovered and brought into focus through the prism of a conscience restricting itself scrupulously to what it had an opportunity to see and understand concerning the laws of the world. The documentary intention is fundamental here: what is described in these works, based on personal experiences which serve as touchstones, is charged with value as evidence, placing these undertakings in the lineage of the personal testimony genre, the documentary function of which was to radically shake up the relationships between literature and reality.

With its origins in legal witness statements, the literary testimony is conceived as a document that establishes facts the author has witnessed, so as to make them public and impossible to ignore or deny, and thus to pay tribute to the departed and to the historical truth that we owe those individuals. With personal testimony writing, the document is no longer either digested for the requirements of the work (it is no longer the hypotext that the work absorbs and transforms ${ }^{7}$ ), nor designated as an "other" distinct from literature (in other words as a fragment of reality preserved unchanged in the body of the text and presented in such a way as to highlight the ontological difference between literature and the world): the witness conceives a work of literature which also has value as a document, with all the implied guarantees (adoption of a point of view, rigorous dating, reference to any source material, etc.) that set it apart 
from "fiction". Since the goal is to provide proof of what is happening or has happened, there is no room for confusion (particularly with the genre of the novel). The action of the witnesses (and those who have followed in their footsteps) therefore consists in asserting factual truth as such. This action seems rather out of place in the field in view of the conception of the "literary" which still prevails", and which in passing encourages a distinction to be made between this project of truthfulness and approaches maintaining confusion as to the work's regime of truth. This confusion is upheld when a book enjoys both the label "documentary" and the extra legitimacy which the status of fiction still bestows today. I think, on the contrary, that one needs to heed the desire asserted by some to place their writing outside the realm of fiction and to accept what that means with regard to the way their works are read and interpreted. The position which consists in considering the distinction between true and false in literature as a serious affair needs to be taken seriously. These authors are writing in the shadow of a twentieth century which took criminal inventiveness to its peak, all the while taking care to erase the traces of its crimes.

In the same way as testimony, the works I intend to study here were written on the basis of a rejection of fiction - or at least, they do without it, and rely on another form of exploratory power than that which is acknowledged in the novel, and this can be beneficial9. Their authors did not set out to invent a world in which to launch characters to experiment with possible configurations, but rather to reveal our world by observing it, by moving within it and inventing specific instruments to account for what they hold to be facts which are verified, significant and worth paying attention to - and remembering. For example, M. Cohen's work, which draws strength from the regularly reasserted desire to "escape from the genre of the novel" (which the disasters of the century have made obsolete),${ }^{10}$ takes the form of a series of books - including a trilogy entitled Faits - designed to collect things which have been seen, read, ${ }^{11}$ heard, experienced, thought or imagined. All of these are "facts" that the author specifies are "easily verified" (Cohen, 2010, back cover notes), and also sources are referenced at the end of the book. Collecting facts in this way, which can be done either in the outside world - often in "non-places", margins, no man's lands, from the outskirts of towns and cities to the open sea (M. Cohen notably reports anecdotes drawn from his travels on a container ship) - or in the inner sphere (where the writing comes to collect facts always first concerning other lives than one's own), engages forms of objectification which borrow particularly from Perec's attempt at exhaustiveness. Perec appears as the missing link between the personal testimony genre and the corpus which interests me here..$^{12}$ These explorations, anthropological in intent, strive to "describe the rest: the things that are generally not observed, not noticed" (Perec, 2008, p. 10) - they are attempts to exhaustively describe a memory, a vision, an impression; attempts which are aware of their limits, disenchanted but not desperate, performed with precaution, and generally completed insofar as they can be ${ }^{13}$. Ethically, we have here a literature which could be described as non-directive, questioning and drawing up lists and leaving the readers free to pursue their options, proposing without making any promises or imposing anything. This literature also, from this perspective, repudiates the narrative - as in the case of M. Cohen, who does not hide his "repugnance" to "organise a story according to the usual criteria of narration" (Cohen, 2010, back cover notes). In reporting, in Sur la scène intérieure (sub-titled Faits), everything he could remember about his eight relatives who were murdered at Auschwitz and everything he was able to learn about them, the writer dismisses both fiction and narration. Not 
only do the fragments of memory which he brings to light not lend themselves to story, but above all the logic of narrative would inject a meaning and produce an effect of disconnection which would betray the data of experience. "By writing a story", says M. Cohen, "I would in many ways have had the impression I was writing fiction" (Cohen, 2016, p. 211.) For the two are linked together. However, while the growing popularity of factualist writing has escaped no-one's attention, it has perhaps been less often noticed that this process has in some cases been accompanied by a move away from storytelling. And this has been all the more difficult to discern because, in order to avoid being encumbered by categories of genres (whose reputation has already been discredited) to designate works belonging to "factual literature", the label "narrative" has often been used for want of anything better to signify their "non-fictional" character, in opposition to the novel. There is a real benefit: "narrative" is at both more "literary" and "much more indeterminate" (Samoyault, 2001, p. 20); the paratextual tag allows these works to regain some of the legitimacy they lost as fiction was abandoned. The paradox is that there is a tendency for a subset of these "narratives" to move away not only from fiction but also from narration, or even to call into question the configurative virtues that are considered today to come with "emplotment" - a remarkable stance in a context of fetishisation of the narrative.

In the wake of the successes achieved during the decade between 1965 and 1975 by structural narratology, the "narrative turn", which fuelled research in the humanities and social sciences from the 1980s onwards, raised the narrative to the rank of a major cognitive structure ${ }^{14}$. The passion for narratology which resulted owes a lot to the work of P. Ricœur, who taught us, through an Augustinian re-reading of Aristotle's Poetics, that our relationship with time finds itself configured by a process of "emplotment" and that our identity is therefore itself "narrative". Since this discovery, which gave a decisive impulse (and a Paulinian colouration) to a theory of the narrative shaped jointly by a liturgical conception of human action and a semantics of action inspired by English-speaking philosophers, the place of narratives was reassessed in all disciplines. This was sometimes for the better, ${ }^{15}$ so much so as to make the narrative conceived in this way one of the major prisms through which knowledge could be rationalised (at the risk perhaps of neglecting other forms of rationalisation of knowledge), or even a way of deciphering a world which was already configured and significant in itself. ${ }^{16} \mathrm{Not}$ that there was, at the end of the twentieth century, an unleashing of unprecedented narrative forms; it was rather a propension to hunt for unsuspected narrative patterns which developed (at the risk perhaps of identifying them where they were not in fact present, given that it is always possible to unearth a fable or rewrite history). This went some way towards compensating for the end of the "grand narratives": there were small narratives to be found everywhere. It then attached to stories a favourable bias, a healthy modesty and all sorts of powers (educational value, healing powers, a springboard for new vocations, etc.) which the theorists of storytelling (the word was even included in the Robert dictionary in 2018) brought with them, drawing our attention to the way politicians, marketing gurus, management theorists and war leaders take advantage of narratives to turn them into instruments of domination (Salmon, 2007) - which, like any form of imperialism, raises the question of what can exist outside them, and a fortiori in literature. And indeed while a certain formalism may have appeared for a time to sow terror in the world of Literature, it has recovered since. The return of the subject and of History in the 1980s marked the final act of this comedy of remarriage which characterises the relationship between literature on the 
one hand and history and stories on the other. In short, while "all-narrative" can make invisible anything which moves outside the narrative in narrative-centred societies such as ours, it can be particularly obscuring in literature, especially in texts which are traditionally related to the so-called "narrative" genres, despite the fact that some of them include configurations which resist logical narrative in ways that are persistent, non-residual and significant. I propose now to turn to some of these texts.

\section{La Clôture by Jean Rolin or the exhaustion of narrative}

Based on the experience of a survey in an area in north-western Paris and on the notes the author made there on the spot, La Cloture sets out to be the reconstruction, by an identified individual, of what he had gleaned over a period of a few months. A reflexive consciousness haunts the area around boulevard Ney and travels through the empirical diversity which offered itself up (the sounds of the city, the temperature, the state of the traffic, the density of the habitat, etc.), with the avowed aim of "writing about ${ }^{17}$ " Marshal Ney from the viewpoint of the boulevard which bears his name" (Rolin, 2002, p. 19) - or vice-versa. The book therefore proposes a survey of an urban area with a fluctuating boundary. ${ }^{18}$ Within this spatial entity with an unstable centre of gravity a whole host of facts - or what the observer constitutes as facts by taking on the role of a witness to the state of the world - can be found. The method employed (observation and encounters) recalls journalistic fieldwork or sociological pre-surveys, although the acuteness of the point of view is only equalled by the non-systematic nature of the prospection. This yields a collection of random data, whose value comes from its contingency, and in which topographical facts take up so much room that they relegate to the periphery the more or less licit human activity which takes place in a neighbourhood which is itself peripheral. Meanwhile, the centre of the book describes the Boulevard Périphérique which passes over rue de la cloture, in a hollow pillar of which lives a certain Gérard Cerbère ${ }^{19}$, along with a few other people with shattered lives. There is no fiction in this place ${ }^{20}$ : factographic writing, which notes (and records) things which would otherwise have gone unnoticed (and forgotten), probes the margins of society and reveals what it relegates to its "non-places". The nodal point of the survey, the observer's point de vue $e^{21}$ is exhibited "as is", both in the sense of viewpoint and point of view: as the guarantor of the observations collected, the discursive instance is located both spatially ${ }^{22}$ and axiologically. ${ }^{23}$ In sum the goal is to objectify a subjective vision in order to shed light on facts, most of which - the curve of a boulevard, a flickering sign, scaffolding covered in dustsheets, stains on the pavement left by Sunday piss, installation of a syringe exchange machine, etc. - are things which G. Perec (1989, p. 12) would have called "the banal, the day-to-day, the obvious, the common, the ordinary, the infra-ordinary, the background noise, the habitual", but which would otherwise have been a dead letter in the eyes of History - which is omnipresent because the (relatively) great deeds of Marshal Ney appear along the vanishing line between the chapters on twnety-first century Paris.

The result is a prose which is precise, heavy with dates, rustling with place names, which carries the collected facts by integrating them into a discourse which it would be inaccurate to call a "narrative". Not that there is no narrative, as we will shortly see, but "writing about" boulevard Ney is not the same as "telling its story". What we are invited to read is rather the evocation of an immersive experience ${ }^{24}$ which gives rise to 
a series of descriptions (places, scenes, people, objects, impressions), sometimes accompanied by explanations or comments. These descriptions owe less to the genre of the "promenade 25 " (in J. Rolin's work, the prostitutes are of flesh and blood) or of "things seen" (at least if the model of the genre is taken as V. Hugo's Choses vues ${ }^{26}$, which navigates between a notebook collecting the sediment of what its author learns day after day - more than the things that he $\operatorname{sees}^{27}$ - and a "diary of the outside" which has little to do with wandering through the city), than to an updating of "flânerie" writing. This update includes the criticism of the consumer society, although the surveyor of the nineteenth arrondissement of Paris differs from the nineteenth-century flâneur through his skills in geometry, his appearance of an old policeman on a surveillance job and the ethos he has of an animal documentary commentator, a kind of "voice off" cultivating an irony with no conviction (a mimesis of disengagement which is perhaps not unconnected with the bankruptcy of the radical engagements of the period of the "grand narratives"). The time is right for observation, sometimes for comment, but the passage ends before narrative takes over.

Rue Charles-Hermite, in the corner of the square, not far from the room where the old ladies, some of whom witnessed the bombing of La Chapelle, meet together, there are in all twelve stray cats on Sunday 9 July in the early afternoon: seven on the pavement, two on the low wall between the pavement and a bin area and three in the bin area itself. (Rolin, 2002, p. 127)

8 This paragraph, which sounds like a catalogue, is alone on the page, with nothing linking this inventory to what comes before or what follows - nothing, that is, except the gaze of the observer in his attempt here, as in other places, to establish a fact, located in time and space, with a reference to a place with a historical ramification (the link with History with a capital $\mathrm{H}$ is still there, the figure of the witness). Apart from the passing reference to Walden by H. D. Thoreau - "It is not worth the while to go round the world to count the cats in Zanzibar" - which sets up a bucolic counterpoint to the genre of urban writing and adds an earthy tone to the criticism of post-industrial society, the fact is not told but reported - and one notes the use of the enunciative present (and not the narrative present) with a descriptive value - and it is not embedded in a narrative, not even a "documentary" narrative. If one wanted to reactivate some old conceptual pairs, one could say that on the one hand discursive enunciation eclipses historical enunciation, and on the other hand that description prevails over narrative, and that it even tends purely and simply to eliminate it. Here, description is conceived here not as a pause in the narrative frame in which it is embedded, but as a mode of expression in its own right, which raises the question as to when a narrative without a plot (one which is not unified by a plot) ceases to be a narrative. If it is understood that action provides the backbone of narratives, one might rather speak here of distanced description of human action. Not that the dramatic intensity or the "event content" are small or weak: they are simply not what it is all about. The mode of composition of the book owes all the less to the twists of a plot as, in a way, "nothing happens" (Rolin, 2002, p. 59) in La Clôture. Not that nothing happens in the peripheral areas of Paris, where everything could potentially contribute to creating an event; but the book that observes this (relative) effervescence is not playing the game of emplotment. In this "faction" writing, the narrative tension is replaced by the descriptive attention of an observer driven by a documentary intention, taking note of "what happens when nothing happens" (Perec, 1974, p. 12). This is a long way away from the survey or the investigation, the dynamics of which rests on 
"emplotment and the creation of an urge to know" (Demanze, 2019b, p. 272): here, the "narrative unbinding" (déliaison narrative) (ibid.) is present throughout the text, and the powers of the narrative are themselves called into question. Thus, the descriptions proposed in La Clotture are in a sense the counterparts of the objects which form the froth of the outer boulevards - profuse, eclectic, fragmentary, "detached from their context ${ }^{28}$ ": inserting them into a narrative weft would modify the meaning of the approach adopted to produce facts. There is no line of action to link episodes together; the sequences here are more like the successive points on a map showing a bus line - a series of "stops". And in fact there is a bus stop called "La Clôture", but no buses stop there because it is just a fake bus stop (p. 147), installed as part of a film set. ${ }^{29}$ To put it another way, La Clôture is no more a narrative than the "La Clôture" bus stop is a point on the Parisian bus network. Playing on this trompe-l'œil which serves as its title, the book formulates a discourse on narrative that could be missed if the text is described as a "narrative" from the outset - whereas to present the fruits of his collection, the observer seems to take particular care to avoid the narrative approach.

This is because, while there is narrative here, it is less as an overall structure than as an object of discourse - an object which is carefully examined from various angles and which seems to generate a form of distrust. This happens when the object is designated as a problematic matrix of the text, as in the narratives which "need to be approached with a certain amount of caution" (p. 70) that the observer collects as he walks through the area, which are "sometimes contradictory, with a relatively high margin of uncertainty" (p. 95), and of which we only hear weakened and distanced echoes, as he is keenly aware that he may also have "modified or distorted them, in good faith or in bad faith, by reproducing them" (p. 70). Distrust also emerges when the object is an outdated model, such as with La Vie militaire du maréchal Ney, duc d'Elchingen, prince de la Moscowa, "an unfinished work by general Bonnal ${ }^{30 "}$ ", which the flâneur of boulevard Ney skimmed through - "because he was a bit of a bore, General Bonnal" (p. 15) - along with other biographies and points of view of key people at the time who were more or less concerned about their "effects on posterity" (p.65). The summary and half admiring and half ironical ${ }^{31}$ commentary on this "tragic fate" (p. 17) including his rise and fall ${ }^{32}$ (but also cavalry charges, bayonet attacks, fleeing soldiers cut down by the enemy's swords, heaps of bodies, triumphal parades, flair, intrigues, pride and gunfire) are inserted between the descriptive sequences of the outer boulevard, producing a striking contrast. These destinies of yesteryear, full of adventures, have been replaced by lives of immobility - "So it is that Gérard Cerbère just sits there all year long, or at least practically all the time, inside the pillar" (p. 68) - and in the process of fading away: that is the case for Roger, who either sleeps or goes out begging, or Jacques and his drunken stupors, both men "so untalkative that they end up being almost invisible" (p. 92). The military epic is out of place under the Boulevard Périphérique, and the narrative as a structure under tension rushing towards "inevitable catastrophe" (p. 79) is a bit like a relic in a world where there have been so many catastrophes. That is also what description tells us as it replaces narrative: not only is that History dead and gone, but all the "historical" characters have disappeared with it (p.68), their "mythicised" stories (those of the "national novel" that J. Rolin refers to through his Ney, a "disastrous" hero) and, perhaps, the very possibility of storytelling and facing the facts; Gérard Cerbère will never have a boulevard named after him. 
Looking to find the noise of the battle of Hougoumont in the din of the interchange at the porte de Clignancourt, the surveyor ends up in a "place that was so dreadful [...] with its piles of rubbish, its puddles of sump oil and other corrosive fluids, wrecks of burnt or stripped cars and scattered remains of broken lives (I weigh my words), rotten sleeping bags or old foam mattresses, that even a reference to the Battle of the Berezina would have been out of place" (p. 113). The disasters of history pale beside the disasters of the third millennium. The aberrations of the consumer society deprive history of its meaning - not only History but also the little stories of which, on the outskirts of the city, only a few fragments remain. The narrative false starts which are strewn throughout the text bear witness to this, sorts of embryonic stories which form here and there before bursting like bubbles: an aborted plan for a fiction ${ }^{33}$, stories nipped in the bud ${ }^{34}$, etc. In the last chapter, some stories do begin to take off, all of them linked to Charles de Gaulle airport, but in the end, nothing really gets off the ground in terms of a story. In this way the margins of Paris and their "such precarious conditions" (p. 248) end up taking on the role, in La Cloture, of chronotopes of the contemporary world at the beginning of the twenty-first century (since this is the threshold that the book explores): after the wave of consumerism has swept everything away as it passes, the shapeless edges of the peripheral zone are littered with unrealised narrative promises, like so much debris of the neo-liberal era. One understands that a "war" is taking place (p. 116), as witnessed by the unease among municipal workers (p. 144), "business of all kinds" (p. 103), urban "anti-prostitution" initiatives (p.134) and other "poor man's traps" (p. 151-152), the hidden embankments where women are stabbed to death and all sorts of sordid incidents - someone firing randomly at the boulevard périphérique with a shotgun (p. 103-104), a "pair of legs tied up with wire" being fished out of the canal" (p. 136), etc. The observer, who had gone out on reconnaissance, ends up turning his field of observation into his "personal battlefield" (p.118), a battle that he is fighting to try and document the reality of the social world. The work that emerges from this attempt contains a criticism of the consumer society (in which goods, bodies and stories are consumed ${ }^{35}$ ) and its deregulated exchanges. Ultimately, it is the "empire of the virtual" which is identified as the enemy (p. 104, 115). An empire in which the film set bus stop called "La Clôture" and the "fake rubbish" that litters the real rue de la clôture ("because it is unthinkable that the film crews would have used real rubbish") are a possible figure (p. 147-149), charged at the same time with announcing a conclusion. An empire whose heart resides, in the end, in the neon displays which revolve on top of the high buildings, shining like stars, dominating the city and the world. ${ }^{36}$ The criticism of narrative begins to look like a kind of "anti-storytelling". The zone is sad and the narratives lie to us; while the big commercial brands swell up to become history (the essence of storytelling), the surveyor goes out and collects from the ground below the skyscrapers the evidence of the wreckage, to which a disaster-struck and starless humanity and open air rubbish tips bear witness, and in that very act prevents these idols from continuing to tell their own stories.

\section{"Naturally no narrative": the exploratory enterprise of Annie Ernaux}

11 Having entered into literature through the novel, , A. Ernaux rapidly and ostensibly turned her back on it, asserting a "clinical" form of writing, which is all the more biting 
as she claims it falls "outside fiction" (Ernaux, 2011, p. 36). Her project, which is to "explore exterior or interior reality" (ibid.) is an ethical project - "moving in the direction of truth" (Ernaux, 1987, p. 45) - which involves a demanding programme: "to persevere to the end" ${ }^{37}$ in her search for feelings, memories or ideas, and writing "with no other rule than precision" (Ernaux, 1997, p. 51) - a surgical precision for attempts at exhaustivity which seek to leave no stone unturned ${ }^{38}$. This means relying on notes taken at the time of the facts - and she draws from a diary and a personal record of the year 1952 "the evidence and proof" of what she writes in L'Événement (Ernaux, 2000, p. 26). This also means locating in time not only the facts reported - "recording the date is for me a necessity attached to the reality of the event" (ibid., p. 76, n. 1) - but also the words themselves which are used to report them: the date at which the manuscripts were written is scrupulously indicated at the end of her books ${ }^{39}$, as is required for any document. Her concern for the exactitude of facts can for example lead her to travel to Normandy to go and check the shape of a roof. She does not seek to obtain what in a novel one would have called a "reality effect", but because the accuracy of the description with regard to the sensitive experience of the writer is the very objective of this writing, where feeling takes on the role of a "criterion of truth" (Ernaux, 2011, p. 41), to the exclusion of all others.

Mutatis mutandis, A. Ernaux puts her own spin on what the first authors of personal testimonies, survivors of the First World War, did by reporting exactly what they had seen, understood and felt on the front, without referring to any pre-existing models of writing. They strove to keep to the facts so as not to allow their experience to be confiscated not only by bellicose and heroic patriotic discourses, but also by an entire established literary tradition - the very tradition which, feeding them full of epic illusions, had not prepared the soldiers of 1914 for what awaited them on the front line. Their (literary) project: to make it possible to write the truth about a war they had really experienced, so that nobody could find themselves trapped in a trench without knowing. ${ }^{40}$ To counter the habitual representations of the reality of war, which sometimes went so far as to stand between the witnesses and their own experiences and distort their accounts, the authors who had themselves witnessed the war relied on their memories and their feelings. The truth of their accounts is guaranteed by the fact that they were physically present. But staying as close as possible to feelings means precisely writing against a certain form of writing - and requires a certain sobriety. A. Ernaux's "flat writing" (1983, p. 24), unadorned by any stylistic effect, and which is even self-effacing when confronted with the horror of the facts ${ }^{41}$, converges there too with the genre of personal testimony, which distrusts excess in any of its forms. ${ }^{42}$ By restraining the style the goal was to avoid "making" literature, to take control of literature and not allow it to speak through the writer, and not let events tell their own story - so the choice of sobriety acted to the disadvantage of narrative and its secondary effects: its tendency to create euphemisms and make things seem banal. ${ }^{43}$ And above all narrative gives meanings which are not in the things themselves. Thus, A. Ernaux does not tell stories ${ }^{44}$ : she describes facts, actions, objects and images, working on them exhaustively, often preferring noun phrases, which make it possible to escape from the order of actions, and she puts these descriptions together end-toend in the only "order" conceivable for her (Ernaux, 1987, p. 73). This order is indexed to the reality of the object she is trying to grasp according to the type of analysis she deploys around it, and it only enters the realm of narrative when the reality concerned requires it (in L'Événement, for example, to which we will return later). 

"factographies" might represent "an alternative to the narrative as a dominant form in the ordering of reality and experience". Among A. Ernaux's works, she studies Journal $d u$ dehors and La Vie extérieure from that angle, two books devoted to the exploration of the outside world and exhibiting an openly discontinuous form of writing - one which in that respect is manifestly "factographic". In the books in which A. Ernaux explores "inner" reality, the writing seems less disjointed, more continuous. But does that mean that she returns to the narrative? Should one not on the contrary consider that the facts reported in Passion simple or La Honte, although they take place in the inner sphere, do so in a way which leads just as much to a failure of narrative? While the documentary dimension here no longer concerns facts and actions gleaned from the public sphere, the author engages in the same work of objectification of facts of experience in order to record them, and most often their reconstruction escapes from the logic of narrative. Underlain by the search for the "ideal order which is the only one able to render a truth" (Ernaux, 1987, p. 43-44), the "factographic" alternative to the narrative may take different forms.

For example, in Passion simple A. Ernaux does not tell a love story, nor even the story of a bodily passion, as addictive as it was senseless. She depicts the state of dispossession of a woman who had become incapable of doing anything else but to wait for a man, so much so that the world only had meaning for her in its relation to him. To do this, she proposes a list of symptoms - a list which constitutes a document on the forms of feminine alienation which characterise heterosexual relationships in a society marked by male domination. ${ }^{45}$ Because the same causes produce the same effects, there is a similar symptomatology in L'Occupation where this time the world revolves around a woman she has never met but of whom she is jealous, and the obsession is just as vivid.

In both cases, the writing comes to record the effects of a passion (desire or jealousy), the manifestations of which are described one by one (rather as the patient lists, before a medical examination, the symptoms from which she suffers, for fear that forgetting any one of them might make the diagnosis incorrect). ${ }^{46}$ She relates everything which goes against her habits, her tastes and what she knows about herself, everything which she has seen herself become and which she had never thought she would be able to, ${ }^{47}$ superstition appearing as one of the most frequent forms of dispossession . "I thought 'so I've reached that point too', without being surprised. I could see no reason why I shouldn't reach that point" (Ernaux, 1991, p. 53.) It is precisely for that reason that she writes: because an obsession like that, unimaginable for the very person who finds herself confronted with it, is not just a unique and anomic outburst but something which is, if not "normal", at least governed by social norms. And this is what gives her books their exemplarity ${ }^{48}$ : the things that are brought to light are shown because they are the product of a norm which has been made invisible. It is in this perspective that she gives pride of place to the principle of listing symptoms, occasionally radicalised and highlighted by the use of inset paragraphs and the abandonment of capitals at the beginning of the line, which materialise the list (ibid., p. 14, p. 27-30). In this way, she presents but neither explains nor gives a diagnosis (it is not her role to propose a diagnosis); she lays things out without looking for any hypothetical causes on which she could count for help: no cure in sight, no attempt at reparation of the kind found so frequently in contemporary literature (Gefen, 2017). She explores without staging this exploration; without proposing the slightest narrative which would have introduced 
tension, imposed a meaning, provided a glimpse of the possibility of resolution (or of a moral to the story). In doing this, the individual who is "occupied" by narratives breaks with one of the logics of obsession, which feeds precisely on what the obsessed person compulsively narrates to him/herself: daytime dreams or nightmares which may take on a hallucinatory character (ibid., p. 44-45), a scenario which could lead him or her into a half-fictional, half-perverse pursuit (Ernaux, 2002, p.44), etc. A veritable pathology of storytelling, obsession turns into a machine which produces cause and effect relationships ${ }^{49}$ - a runaway production of interpretation akin to incantatory attempts to influence fate. Inhibiting the narrative also means going against the grain of this logic.

The title Passion simple, in which the adjective could be taken as synonymous with "desentimentalised" (ibid., p. 62), is very revealing of this process of sidestepping with regard to narration: apart from the fact that it recalls the use of the word in molecular chemistry and its "simple substances", in other words not compounds, it is also used to designate the past simple, the tense of narration par excellence, as the feature which is most significantly absent in the book. With only two exceptions, which can be found in a meta-discursive development attempting to define the writing project from the point of view of what it is not:

I am not writing a narrative about a love affair, I am not telling a story (which half escapes me) with a precise chronology "he came on November 11" or an approximate chronology "weeks went by". There was nothing in this relationship for me, all I knew was presence or absence. I only accumulate the signs of a passion, constantly oscillating between "always" and "one day", as if this inventory was going to let me reach the reality of this passion. There is naturally here, in the lists and description of facts, neither irony nor derision, which are ways of telling things to others or to oneself after having experienced them, and not of feeling them on the spur of the moment. (Ernaux, 1991, p. 31, the italics are mine.)

It is first and foremost out of a devotion to accuracy that she keeps narrative at a distance: because an obsession is experienced in the hallucinatory mode which consists in powerlessly observing the effects that the obsession has on oneself, and because the inventory was produced in a state of stunned shock close to that which is described (shortly after the departure of A.). In other words, it is the data of the experience itself, characterised by an impaired relationship with time, which cause the narrative to fail: "I was no longer anything but time passing through me" (ibid., p. 20). Accumulation is destined to record not only the litany of pain but the "prolonging - which [to her] appeared endless - of suffering" (Ernaux, 2002, p. 35). The result, in both Passion simple and L'Occupation, is that there are discursive markers of unbounded temporality, dominated by a "secant" imperfect suggesting iteration, associated with some rare singulative scenes (examples of hapax-symptoms), which themselves are rarely located in time - this unmoving, traversing time, providing few points of reference ${ }^{50}$. If there remains a residual narrative logic, it consists in a simili-chronology, a temporal succession with no logical succession- and for good reason because it does not command the causal relationships which govern the symptoms either. And all of this does not even constitute stages like the Stations of the Cross, for they are engraved elsewhere: precisely in the city of Florence, where she has "literally" inscribed her passion in the streets as she wanders through the town (Ernaux, 1991, p. 50). "So all I would have to do to read this story of a woman in love with a man is to go back there" (ibid., p. 51) - a "story" which is to remain the "unwritten novel", of which the text we are reading is no more than a "residue" (ibid., p. 69). 
Like witnesses reporting what they have been given to see, A. Ernaux does not allow herself the liberty of reinjecting a temporal or causal logic which was missing at the time of the experience itself, or where the perspective necessary to understand the processes involved was lacking. What "takes place", happens and changes, and could be formulated within the framework of the temporality of action, is not among her competences: "I cannot report the exact transformation of my passion for A., day after day, but I can only focus on images and isolate the signs of a reality" (ibid., p. 67, n. 1). Not that change does not interest her, but change can only be grasped, from the point of view of the involved witness, by means of snapshots, and this holds true whatever the timescale considered - jealousy over a period of a few months in L'Occupation, sixty years of changes in French society in Les Années (Ernaux, 2008). It can, it is true, be said that the witness's field of vision is limited, but that is also what gives it its value. The tight focus on experience, the ethical choice to restrict oneself to what one knows can make it possible to gain in analytical precision what is lost in narrative tension.

Another example: La Honte opens with a description, covering three pages, of a traumatic episode (her father trying to kill her mother with a sickle one Sunday in June 1952), which set off for her a disenchantment with the world characterised by a hyperconsciousness of class relations secreting an endless shame. The approach adopted is, once again, anti-narrative: the book is not intended to tell a story - that of her "entry into shame" (Ernaux, 1997, p. 116) - of which that scene would be the peak. If the woman remembering "revealed everything at the outset" (ibid., p. 32), it is on the one hand because that does not constitute a real "story" 51 , and on the other hand because the truth that she is searching for, four decades later, escapes any narrative logic. Worse, narrative logic would be likely to hinder the search for the truth: "Naturally no narrative, which would produce a reality rather than searching for it" (ibid., p. 40.) Searching for it rather implies "moving" the scene, so as to uncover its hidden logics, unperceived by the girl who was at that time living in a form of "social innocence" (ibid., p. 116), looking at that moment from various angles and widening the focus of the family photos to include the topography of Yvetot, as well as the local archives and the description of socially codified actions and words which graft the universe of the individual on to the social world. And so her way of questioning reality consists in accumulating evidence produced by a body which has incorporated her shame, in a book whose goal is to make legible, visible, a social hierarchy which she was back then only discovering, and to represent it from the point of view of the person who lived through that experience, treating the images of memory as "documents" (ibid., p. 40) and breaking free of any causal logic to index the movement of the text to the rapidly changing states of her shame- which is itself nothing more than "repetition and accumulation" (ibid., p. 139).

20 A contrario, trying to study a subject as closely as possible without calling on extrinsic logics sometimes requires the introduction of a narrative temporality. For example, the experience of clandestine abortion in 1960s France defines a pathway which obliges the author who sets out to document it to use narrative. The "exploration" which A. Ernaux conducts in L'Événement (2000, p. 26) must be woven "into the weft of a narrative, which is the only way to depict an event which was only a time within and outside me" (ibid.): feverishly waiting for periods, which never come; the result which arrives and retrospectively circumscribes that very special time of being "in the process of getting pregnant" without knowing it (ibid., p. 22); the frantic search for a way to terminate the 
pregnancy; the "shapeless thing" growing inside; the slow, stagnant passage of time and the growing urgency; the unsuccessful attempts; the despondency, the powerlessness, the long hesitations which precipitate her into the hands of a no doubt grasping old woman; waiting for the "deliverance" which arrives in the form of a haemorrhage sending you rushing to the Hôtel-Dieu hospital; the pride of the body once all of that is over, etc. "With this narrative, it is a fragment of time which had been set in motion and dragged me along with it despite myself" (ibid., p. 26): depicting the experience of abortion as hundreds of thousands of women in 1960s France went through it involves, in this case, relating the "event" with the passing of time which is consubstantial with it. With all the problems this entails for A. Ernaux, given her usual preferred approaches: "I feel that the narrative is pulling me along with it and imposes, unbeknown to me, a meaning" (ibid., p. 48). She is not happy about resorting to narrative but the documentary ambition leaves no choice.

Incidentally, it is interesting to note that the passage from Armoires vides (1974) to L'Événement corresponds precisely to the re-establishment of the experience of abortion as it was lived through in its chronological progression where, in the novel, the wait for deliverance was the opportunity for a bout of introspection on the part of the heroine rooting over her life to understand how she had got there. It is the genre which imposes that: "While many novels related abortions, they did not provide any detail as to how it happened exactly. There was a gap between the time when the girl found out she was pregnant and the time when she was no longer pregnant". (Ernaux, 2000, p. 40.) Les Armoires vides (Ernaux, 1974) had replaced this ellipsis with what G. Genette would have called a "complete external analepsis", but A. Ernaux's novel remained in part dependent on that tradition (even though the scene of the abortion was not glossed over). L'Événement puts things back on track by re-establishing the narrative of a journey. The passage from one genre to the other is interesting through what it tells us about the documentary - or even testimonial - ambition of the author, whose only certainty is expressed as follows: "Things have happened to me so that I can portray them" (Ernaux, 2000, p. 125). If she had stuck with the novel, she would not have been able to repay the debt which she owes to all those who have not been as lucky as her: she would not have contributed to shedding light on "women's reality" (ibid., p. 58). And indeed one does not read Les Armoires vides in the same way as one reads L'Événement, even if these books are the result of the same experience, and even if, each according to its genre, they can give information about a practice. In L'Événement, the author bears witness to what she has seen, and what she can assert: the attitude of the medical profession, the refusal of help from the family planning association, the unmarried mother treated like an animal in the Hôtel-Dieu hospital, the duty intern assaulting her during the night of 20 to 21 January 1964, whose name "she could not have helped" telling if she knew it (ibid., p.112), etc. - so many accusations that an abortion in a novel would not be able to make.

Thus A. Ernaux's work is radically different not only from "autofiction" (which is quite the opposite of her project) and also, to a certain extent, of "self-narrative". Everything about this stance is problematic, since not only does A. Ernaux distrust the "narrative" form to such an extent that the movement of her books seems dictated by the desire to find alternatives to suit the subject at hand, but above all because the "self-narrative" points towards autobiography. Although she writes in the first person, just like the authors of personal testimonies whose voices are necessarily positioned, she pays little attention to the "self" as literature has instituted it, because that is not her subject ${ }^{52}$. So 
much so that the ferment of several of her books resides in an experience of dispossession of the "self" - precisely when "there no longer is a self" (Ernaux, 2016, p. 11) and when this failure has its rules in the social world, her experience only being (re)produced to shed light on these rules. Similarly the survivor who bears witness does not tell his life story; he describes what he has seen and understood of the conditions in which others died, thus proposing a contribution (among others) to the writing of History. A. Ernaux does not talk about herself ${ }^{53}$ but about what interests everybody in the things she has experienced and tries to objectify..$^{54}$ Neither autobiography nor analysis, ${ }^{55}$ the exploration she conducts constantly tears her away from the "trap of individuality" (Ernaux, 1983, p. 45).

\section{Literature in question}

Ultimately, collection is a process which is intended to be collective in the sense that, according to the programme of archiving the "infra-ordinary" defined by G. Perec (1989), everybody is called upon to become witnesses of the world themselves, which is tantamount to inciting everyone to become a writer. This is some way away from a certain idea of the Writer (who, in these early years of the twenty-first century, is in better shape than one might imagine), ${ }^{56}$ and also from a certain conception of Literature since the work of literature ceases to be an end in itself and at the same time takes on the role of a document tasked with recording evidence. This dual desacralisation, of Writers and of their Work, is accompanied by a tendency towards secularisation of the field of literature which partially challenges its autonomy. ${ }^{57}$

This collection of data does leave an important role for other fields of knowledge there again following on from what literary testimony has instituted, conceived as a legacy to posterity in general and a gift to science in particular. Because, mindful of the modesty of their contribution and aware that their texts required a specific critical reading, the authors of testimonies and the theorists of the genre have, since the pioneering work of Jean Norton Cru (2006 [1929]), constantly sought to bring their texts to the attention of researchers in the humanities and social sciences, soliciting from them the expert skills that are alone able to assemble a cluster of converging truths to serve historical truth. It is in this perspective that those who record memorable facts (however inconsequential) have worked to make them immortal, pass them on to the sagacity of the readers to which P. Levi attributed the status of "judges" (1987, p. 191), and more generally place at the disposal of posterity an archive made up of facts of experience,$^{58}$ an archive which is also an ark - the sort of ark one likes to be able to rely on when the weather gets rough. In doing this these writings attempt to preserve what must be saved from disappearance and annihilation - in particulier when this disappearance and annihilation are the result of political intent. Thus M. Cohen strives, without harbouring any illusions as to the power of books, ${ }^{59}$ to save everything that still remains of his murdered family. In this ark evidence accumulates as a reminder that the facts are there - not in the sense that they would speak for themselves, but in the sense that, by entering into literature, they acquire an imprescriptibility which serves their cause. For there is indeed a cause to defend, the "essential" according to G. Perec (1989, p. 10) being connected with the "truly intolerable, the truly inadmissible". Whether the goal is to collect evidence to put on trial the economic, warlike or genocidal machine, these inventories, which are often close to an indictment, are in no 
way a kind of weak patrimonialisation: they are based on the conviction that, as M. Cohen says, "this world can no longer be accepted as it is", ${ }^{60}$ that one can only denounce it by bringing to the consciousness of the living all those things which demand attention and vigilance. The facts are there and available to anyone who wants to use them, and especially to researchers (historians, sociologists, psychologists, linguists, etc.), who are among the privileged recipients of these writings. It is up to them to derive from them the necessary narratives. This explains why this evidence is not placed under tension in an overall narrative which would from the outset have narrowed their meaning.

The book that F. Viscogliosi devoted to his parents, who died in the Mont Blanc accident on 24 March 1999, deploys an interesting line of thinking in this respect. Deliberately abandoning the models of the judicial enquiry and the intense media coverage (which appear in counterpoint in the text), he stays down at the level of the facts as they appeared to him, or as he remembers them ten years later ${ }^{61}$, without adopting the perspective from above that would come with "emplotment". He sticks to what he knows, to his case - one among so many others: "I would like to tell the stories of Ernesto, Patrick, Maurizio, Bruna, René, Stefano, Jean-Michel, Ambroise, Gabrielle, and so many others. I would like to, but no, suddenly I lack the courage and the inclination" (Viscogliosi, 2011, p. 19.) Nor will he narrate the death of his parents, which could only be based on "suppositions" (ibid., 12 sq.). He will not tell stories. And he is a little resentful of those who do, like Hitchcock for example, for his "cunning ability which always drags his characters away into troubled waters, for the beauty of the picture. By what right? The deadly pursuit in North by Northwest? Couldn't Cary Grant just sit under a tree and wait for a bit? Do nothing, want nothing. Just wait." (ibid., p. 136--137). Giving priority to attention instead of tension, the text points to North by Northwest as a "good example" of those well-crafted narratives which "in the past, in the twentieth century, ,...] we would watch over and over again" (ibid., p. 133), and which represented "a starting point from which to survey the world" (ibid.). Mont Blanc notes that this point has moved, and with it our relationship with storytelling (and suspense). In the twenty-first century, we scrupulously list the facts we hold, and which we suspect may be clues about something, but we are reluctant to reconstruct the narrative in which these clues would take on meaning. The hunters are tired, and their stories- "[c]avalcades in the thickets, stalking and pursuits" (ibid., p. 70) - belong to another era. Just like, perhaps, the paradigm of clues. We continue to live surrounded by traces, which awaken presumptions, or even prompt hypotheses, but if we stick to the traces, we preserve them for what they are: pieces of evidence, which other people will strive to put together.

The appeal made by G. Perec to shift one's attention from the realm of events to the essential has been heard; new ways of recording daily life have appeared in literature. But has this programme - taking note of what one sees happening (around one or within one) and whose memory one wants to keep, objectifying these facts of experience through a writing process that gives them their meaning, entrusting the book with the mission of testifying to them - led to an extension of the infra-ordinary to the testimonial project? Have the upheavals that this (political) project of manufacturing a collective memory entails with regard to the very idea of literature been fully appreciated? When "fiction" is challenged to the benefit of an attempt at truthfulness anchored to a reality of experience with no possible compromise? Or when a style is developed which is quite the reverse of the expected models of "diction"? And 
when, finally, the "emplotment" - which is supposed to compensate for the absence of fiction and/or diction in non-fiction prose writing (Genette, 2004, p. 115-116) - is itself subjected to criticism in those works which invent other modes of representing reality, then there is not much left of Literature as conceived in its romantic determination, in the orbit of which most of the literary field still gravitates. Not "taking first and foremost the side of art" (Ernaux, 1987, p. 23), ${ }^{62}$ means breaking away from the current æsthetic regime - that same regime which always made P. Levi (1998, p. 106) feel like a "foreign body" in the world of Letters, and which still leads M. Cohen (2016, p. 211-212) to specify, about Sur la scène intérieure (a masterpiece) : "This is not a work of literature". There are indeed some beneficial breakaways.

\section{BIBLIOGRAPHY}

ANTELME, R. (1957) [1947]. L'Espèce humaine. Paris : Gallimard.

BARONI, R. (2016). «L'empire de la narratologie, ses défis et ses faiblesses ». Questions de communication 30, p. 219-238. Online: https://www.cairn.info/revue-questions-decommunication-2016-2-page-219.htm.

COHEN, M. (2002). Faits. Lecture courante à l'usage des grands débutants. Paris : Gallimard. COHEN, M. (2007). Faits. II. Paris : Gallimard.

COHEN, M. (2010). Faits. III. Paris : Gallimard.

COHEN, M. (2013). Sur la scène intérieure. Faits. Paris : Gallimard.

COHEN, M. (2016). « Faire avec presque rien ou Le métier d'un écrivain stupéfait ».

Europe 1041-1042, p. 207-220.

COHEN, M. (2017). Autoportrait en lecteur. Marseille : Éric Pesty.

COLLECTIF MAUVAISE TROUPE (2014). Constellations. Trajectoires révolutionnaires du jeune $21^{\mathrm{e}}$ siècle. Paris : Éditions L'Éclat.

CRU, J. N. (2006) [1929]. Témoins. Essai d'analyse et de critique des souvenirs de combattants édités en français de 1915 à 1928. Nancy : Presses universitaires de Nancy.

DEMANZE, L. (2019a). « Fictions d'enquête et enquêtes dans la fiction ». COnTEXTES 22. Online: http://journals.openedition.org/contextes/6893.

DEMANZE, L. (2019b). Un nouvel âge de l'enquête. Portraits de l'écrivain contemporain en enquêteur. Paris : José Corti.

ERNAUX, A. (1974). Les Armoires vides. Paris : Gallimard.

ERNAUX, A. (1983). La Place. Paris : Gallimard.

ERNAUX, A. (1987). Une femme. Paris : Gallimard.

ERNAUX, A. (1991). Passion simple. Paris : Gallimard. 
ERNAUX, A. (1997). La Honte. Paris : Gallimard.

ERNAUX, A. (2000). L'Événement. Paris : Gallimard.

ERNAUX, A. (2002). L'Occupation. Paris : Gallimard.

ERNAUX, A. (2008). Les Années. Paris : Gallimard.

ERNAUX, A. (2011) [2003]. L'Écriture comme un couteau. Entretien avec Frédéric-Yves Jeannet. Paris : Gallimard.

ERNAUX, A. (2016). Mémoire de fille. Paris : Gallimard.

GEFEN, A. (2017). Réparer le monde. La littérature française face au XXI $I^{e}$ siècle. Paris : José Corti.

GENETTE, G. (2004) [1991]. Fiction et diction. Paris : Éditions du Seuil.

GONCOURT, E. \& GONCOURT, J. de (1956) [1887]. Journal. Mémoires de la vie littéraire. Paris :

Robert Laffont.

HUGO, V. (2009) [1887]. Choses vues. In : Euvres complètes. Paris : Robert Laffont.

JABLONKA, I. (2014). L'Histoire est une littérature contemporaine. Manifeste pour les sciences sociales.

Paris : Éditions du Seuil.

KELLER, E. F. (2004) [2002]. Expliquer la vie. Modèles, métaphores et machines en biologie du

développement. Translated from the English by S. Schmitt. Paris : Gallimard.

LEVI, P. (1987) [1947]. Si c'est un homme. Translated from the Italian by M. Schruoffeneger. Paris :

Julliard.

LEVI, P. (1998) [1997]. Conversations et entretiens 1963-1987. Translated from the Italian and English by T. Laget, and from the German by D. Autrand. Paris : Robert Laffont.

PEREC, G. (1980). La Clôture et autres poèmes. Paris : Hachette.

PEREC, G. (1989). L'Infra-ordinaire. Paris : Éditions du Seuil.

PEREC, G. (1992) [1963]. « Robert Antelme ou la vérité de la littérature ». In : Une aventure des années soixante. Paris : Éditions du Seuil, p. 87-114.

PEREC, G. (2008) [1975]. Tentative d'épuisement d'un lieu parisien. Paris : Christian Bourgois.

REVAULT D’ALLONES, M. (2018). La Faiblesse du vrai. Ce que la post-vérité fait à notre monde commun.

Paris : Éditions du Seuil.

RICCEUR, P. (1983-1985). Temps et récit I, II, III. Paris : Éditions du Seuil.

ROLIN, J. (2002) [2001]. La Clôture. Paris : Gallimard.

RosanVallon, P. (2014). Le Parlement des invisibles. Paris : Éditions du Seuil.

RUFFEL, L. (2012). «Un réalisme contemporain : les narrations documentaires ». Littérature 2 (166), p. 13-25. Online: https://www.cairn.info/revue-litterature-2012-2-page-13.htm.

SALMON, C. (2007). Storytelling. La machine à raconter des histoires et à formater les esprits. Paris :

Éditions La Découverte.

SAMOYAULT, T. (2001). Littérature et mémoire du présent. Nantes : Éditions Pleins Feux.

VIARD, D. (2018). « Les littératures de terrain. Enquêtes et investigations en littérature française contemporaine ». Cahier ReMix 7. Online: http://oic.uqam.ca/fr/remix/les-litteratures-deterrain-enquetes-et-investigations-en-litterature-francaise-contemporaine. 
VISCOGLIOSI, F. (2011). Mont Blanc. Paris : Stock.

ZENETTI, M.-J. (2014). Factographies. L'enregistrement littéraire à l'époque contemporaine. Paris :

Classiques Garnier.

\section{NOTES}

1. This also means according to the epistemological logic, with a touch of ontology, which characterises the philosophy of language in the English-speaking world.

2. For reasons which are rooted in its history and in the sociological and ideological structuration of the field, literature had ended up defining itself almost totally - in France at least - as "fiction". This shows in particular the difficulty that genres like autobiography, diaries, reportage or testimonials have experienced in existing, as literature, in the eyes of criticism, although at the same time critics have not attempted to defuse their power to record reality.

3. The collection posted by P. Rosanvallon on the site site raconterlavie.fr, and in the "Raconter la vie" collection published by Seuil (see Rosanvallon, 2014), which seeks to constitute "the real novel of French society", or the "pragmatic narratives" called for by the Mauvaise Troupe Collective in Constellations (2014).

4. That said, this trend remains a minority, even within the restricted centre of production in which it has its place; literary narratives still very substantially predominate the field.

5. Among them, in the French domain: La Clôture by J. Rolin (2002), Daewoo by F. Bon (2004), Anthropologie by É. Chauvier (2006), Un livre blanc by P. Vasset (2007), On n'est pas là pour disparaître by O. Rosenthal (2007), Récits des marais rwandais by J. Hatzfeld (2000-2007), Le Quai de Ouistreham by F. Aubenas (2010), Histoire des grands-parents que je n'ai pas eus (2012) and Laëtitia ou La Fin des hommes by I. Jablonka (2016), Au fond by P. Artières (2016), and all E. Carrère's books published by POL since L'Adversaire (2000). It should however be noted that still today, it is rare for authors to enter into literature through the "non-fiction" route in France. For those who do take this step, the abandonment of fiction often represents a crucial, and perhaps irreversible, point of passage in their work (one thinks of A. Ernaux and E. Carrère).

6. One should also note the Renaudot prize awarded to E. Carrère for Limonov in 2011, and of the Médicis prize given to J. Hatzfeld for La Stratégie des Antilopes in 2007 and to I. Jablonka for Laëtitia in 2016.

7. One is reminded of the "beastly and ugly document" which some nineteenth century novelists used to build their novels (Goncourt, 1956, p. 1081).

8. And indeed these works baffled the critics, who either took their efforts at transparency for dull literality, unworthy of a work of art, or relegated them, out of habit or convenience, on the side of "fiction" allegedly inherent in any narrative configuration - and a supposed guarantor of "literarity" (Fiction et diction still reconfirmed this in 1991).

9. "A new horizon emerged at the same time as I rejected fiction, all the possibilities of form opened up" (Ernaux, 2011, p. 22.) 
10. An intention formulated in the first words of the back cover notes of Faits (Cohen, 2002).

11. In Autoportrait en lecteur, M. Cohen (2017) compiles quotations: apart from five lines of introductory text, not a single word is his.

12. Via, in particular, the illuminating article he devoted to L'Espèce humaine in 1963, « Robert Antelme ou la vérité de la littérature » (Perec, 1992) - but not only there.

13. Rigour may make the dream of exhaustivity come true. When questioned on this point some time after the publication of Sur la scène intérieure (2013), M. Cohen confirmed this, saying that his "great fear was that facts would suddenly spring up once the book had been finished. But no, nothing! In the end I didn't write the book. All I had to do was to transcribe it." (Cohen, 2016, p. 211.)

14. For a health check on narrative theory, see for example Baroni (2016).

15. One thinks for example of the work of the physicist E. F. Keller (2004).

16. P. Ricœur contradicts himself on this point when he claims, in Temps et récit, that empirical diversity is shapeless, and at the same time that the world of action, upstream of emplotment, is always already configured. According to this second version which owes more to the Scriptures than to Aristotle, narrative logic imitates the logic of action as such.

17. For authors seeking to free themselves from narrative, the goal is "writing about". A. Ernaux $(1987$, p. $22,43,68)$ conceived in Une femme the project of "writing about" her mother.

18. During the survey, the area covered shifts two kilometres to the East. This shift, confirmed in the title which does not refer to boulevard Ney but to rue de la Clôture, constitutes the main incident in the book, although the reasons for it are never made clear. But the fact that La Cloture is also the title of a collection of poems by G. Perec (1980) - who appears in one of J. Rolin's books (2002, p. 173) - is unlikely to be coincidental.

19. What can one say about this unlikely surname [Cerberus in English], which is so obviously "invented", in a work which I would describe as "documentary"? In fact, for reasons of privacy, it was slightly modified by the author. But the bar was set quite high because the real name of the occupant of the caravan, Gérard Charron, already pointed towards the gates of Hades. [Note: in French, Charon, the boatman of the river Styx, is Charron]

20. "Everything I describe in La Clôture, all the facts that I write about there, are true, or at least that is how I see them. I would be completely unable to "imagine" a character like Gérard, or, once I had met him in real life, to "fiction" him. (Personal conversation with the author)

21. A point of view which in part inserts that of Marshal Ney, who was defeated by History.

22. What is described is what comes into your field of vision at time $t$. That was the case for the panorama you discover from the window of room 611 of the Village hotel, and of what more you can manage to glean if you lean out "until you almost lose your balance" (Rolin, 2002, p.14), or what you can observe if you lean back against the counter of the Maréchal Ney café (ibid., p. 23). 
23. There are no value-free facts. Although the observer can sometimes, when confronted with the destitution he describes, imitate the posture of neutrality or feigned ignorance which suits the scientist - he is in reality "playing the fool" (ibid., p. 156) more often that he should - he does not attempt to hide his point of view behind the product of his observations.

24. "Evocation" in the strict sense of the word, the dimension of "giving voice" being strengthened by the way the text is produced, because the notes taken in the field (mentioned several times in the text) were recorded on a cassette recorder and then transcribed.

25. A genre which lends itself to reverie in which the philosopher's thoughts (Diderot called them his "catins" [prostitutes]) are the protagonists.

26. It should be recalled that the only time V. Hugo (2009, p. 592) used the title Choses vues himself was about this lunar seascape: "A ship from Norway loaded with pinewood, sailing before the moon with its ropes bedecked with dried cod".

27. For example 30 July 1846: "The sexual organ of a walrus is a bone" (Hugo, 2009, p. 599) or, twelve days later: "St. John the Baptist ate locusts." (Hugo, 2009, p. 601).

28. " [...] beer cans and other drink packaging, cigarette packets, the most common being Marlboro, condoms, bits of clothing - most often shoes - removed from their context." (Rolin, 2002, p. 101).

29. A fake bus shelter was erected in rue de la Clôture during filming of Chaos by C. Serrault.

30. Apart from the fact that the book is unfinished, the edition he has in his hands (at the Fondation Thiers) has never been read to the end because the pages of the third volume have not been cut.

31. The thing that really pleases him about Ney, is that he is "something between the midinette and the variety artist" (Rolin, 2002, p. 18).

32. Born "the son of humble parents", Ney raised himself "to the highest degrees of glory" and then "ended up before a firing squad" (ibid.).

33. A plan "whose two main characters would have been me and Marshal Ney" (Rolin, 2002, p. 70).

34. For example when "three Mariachi musicians" dressed in black, with dark sunglasses and black hats, get out of a big black Peugeot, "each one holding in their arms a guitar case, black like everything else" and walk into a betting shop at dawn: "and nothing happens, because contrary to what everything would have us expect the three guitar cases contain three guitars" (ibid., p. 58-59).

35. Narratives play their role in this when they strike a chord and fit the moment. For example the murder of a Bulgarian prostitute in the rue de la Clôture, "in a cityscape that lent itself to a certain novel-like sensibility" (ibid., p. 38), generates a wave of compassion that was not matched a few months later when an Albanian prostitute was murdered in similar circumstances.

36. One of the most predatory, the Daewoo tower turns out to be the compass of the whole system.

37. This rule that she imposes on herself is regularly formulated in her books and is even included in the quotations selected for epigraphs: "Who knows if memory does not consist in looking at things until the end" (Y. Tsushima in Ernaux, 2000, p. 9) ; « [...] 
and yet if I had the courage to see what I was feeling to the end, I would end up discovering my own truth" (J. Rhys in ibid.).

38. There is always a risk that one might "allow something essential to escape" (Ernaux, 2002, p. 42).

39. For example, Une femme was written between "Sunday 20 April 86 and 26 February 87" (Ernaux, 1987, p. 106), and L'Occupation in "May-June and September-October 2001" (Ernaux, 2002, p. 76).

40. See on this question the first theorist of testimony in literature, J. N. Cru (2006), who undertook in Témoins to produce an analysis and criticism of all personal accounts of French combatants edited between 1915 and 1928.

41. On the subject of her father's body, in La Place: "The smell arrived on Monday. I had not imagined it. A sweet and then terrible stench of flowers forgotten in a vase of stale water" (Ernaux, 1983, p. 17.)

42. See for example the clarification offered by R. Antelme $(1957$, p. 11) in L'Espèce humaine: "I am reporting here what I experienced. There is no overwhelming horror. In Gandersheim there were no gas chambers, no crematoria. The horror there is the darkness, the absolute lack of any point of reference, the loneliness, the incessant oppression, the slow annihilation."

43. "Perhaps the narrative, any narrative, makes any action, even the most dramatic, normal" (Ernaux, 1997, p. 17.)

44. Besides, the narratives that can be identified in her work are partly (or totally) presented as anti-models: the life-stories told in her parents' café-cum-grocery store; the story of her grandmother, "which came to an end when she was eleven" (Ernaux, 1987, p. 25); the story she draws from her abortion which she compares with her friend's abortion (Ernaux, 2000, p. 113); the "collective novel" which the inhabitants of Yvetot build up about everybody else, constructing in fragments the "story of the others", and producing edifying narratives (Ernaux, 1997, p. 66); the game consisting in composing "the story of an ideal day" (ibid., p. 136) starting out with magazine advertisements (advertisements which are far from negligible in incorporating one's shame) ; etc.

45. The way she has of falling for A. is shaped by social norms. Simply, the girl who had "expected", according to the place allotted to young girls, to be "busy" (physically and psychologically) proves to be an excessively good pupil.

46. Besides, the type of spiritual exercise which characterises the attempt at exhaustive recollection of a memory is theorised in Passion simple: after her lover leaves France, she tries to reconstruct in detail the Venetian hotel room she had stayed in before she met him, "striving to remember everything", "listing all the things that were in there, one after the other": attempting, in sum, to "exhaust the content" of that place (Ernaux, 1991, p. 57). In writing on the state to which her obsession had led her, she reiterates this action at another level.

47. "I discovered what I was capable of, which was practically everything. Sublime or mortal desires, an absence of dignity, beliefs and behaviours that I would have found absurdly incongruous in others until I had recourse to them myself" (ibid., p. 76); "Generally speaking, I accepted behaviours which I had formerly stigmatised or which I found hilarious. 'How could anyone do such a thing!' had become 'I could do that too'." (ibid., p. 37.) 
48. "I wonder if I don't write to find out whether other people haven't done or felt the same things, or else, so that they might find it normal to feel them." (ibid., p. 65.)

49. "My ability to connect the most disparate things in a cause and effect relationship was prodigious." (Ernaux, 2002, p. 40.)

50. One of their specific characteristics is the fact that the "date of appearance" of any given sign cannot "be defined with any certainty" (Ernaux, 1991, p. 67, n. 1).

51. Besides, the tragedy from which this scene is derived "did not happen" (Ernaux, 1997, p. 21), and that is also what makes it undecipherable for the person who witnesses it.

52. Furthermore, the patient accumulations which she performs do not construct, even in fragmentary form, a history which would be her personal story and make it possible for people, like the customers at the grocery store in Yvetot, to conclude that "she's a good person" or that "she's not worth much" (Ernaux, 1997, p. 66).

53. On the subject of Passion simple, she writes: "I did not write a book about him, and not even about me" (Ernaux, 1991, p. 76). And similarly the title of the book which she devoted to her mother clearly indicates that she is not talking about her mother but about "a woman". Une femme is no more "a biography" (Ernaux, 1987, p. 106) than La Honte or Mémoire de fille are autobiographical.

54. Similarly M. Cohen (2016, p. 212) asserts, on the subject of Sur la scène intérieure: "I didn't want to talk about myself but I needed a minimum amount of information."

55. "It's quite the opposite of 'working on oneself." (Ernaux, 2011, p. 60.)

56. "I never think of myself as a writer, just as someone who writes, who has to write" (Ernaux, 2011, p. 21.)

57. In the process of institutionalisation of the fields of knowledge which took place in the nineteeenth and early twentieth centuries, the professional organisation of writers developed in certain directions, according to recognised domains of competence. Thus the professionalisation of the historian's craft dispossesses writers of competence to write about the past, and as for the present, it "also escapes them in part with, on the one hand, the development of the informative press [...], and on the other, sociologists who specialise in the study of society" (Sapiro, 2012, p. 504). G. Sapiro (ibid.) deduces from that state of affairs that "there remains for them the future, the only area that has not been monopolised by professionals" - hence the vogue for prophecy. One could however add (what is not yet called) "fiction", which makes it possible to appropriate the three aspects of time - past, present and future - and also to preserve a specific domain of competence which is free from the laws of this world and to assert the boundaries of the field by guaranteeing its autonomy through an autonomist conception of literature, inspired by the first German romantics.

58. One notes the importance of archives, as documents and as places, in these texts: A. Ernaux goes to the archives in Rouen in La Honte (1997, p. 33 sq.); J. Rolin is a regular visitor to the collections of libraries, etc.

59. "Does not what it seemed so necessary to safeguard sink just as surely into silence?" (Cohen, 2013, p. 10.)

60. M. Cohen on A. Veinstein's radio programme, "Du jour au lendemain", France Culture, 21/05/2013. 
61. It is interesting to note that despite this programme, the paperback version of Mont Blanc, in the "J'ai lu" collection, is sub-titled "novel".

62. The reception of A. Ernaux's work could usefully be studied from this angle, observing the way in which some people, in order to legitimise the "great writer", downplay the sociological dimension of her enterprise.

\section{ABSTRACTS}

Taking into account an observable tendency in contemporary French literature to refuse fiction and take a sceptical attitude toward narrative in favour of a factualist form of writing that foils any attempt to tell a story in the traditional sense of the term, this article is based on the hypothesis that what the genre of the personal testimony had introduced into literature has been extended to everyday life: in other words an attempt to objectify the data of personal experience in order to document life as it is actually lived. These works, whose authors reveal, record and save facts for posterity by bearing witness to them - thus assuring that they can never be forgiven or forgotten - contribute to the questioning of a certain idea of what literature is, an idea that still holds sway today.

Partant du constat qu'une partie de la littérature française contemporaine s'élabore à la fois dans un refus de la fiction et dans une critique du récit au profit d'une écriture factualiste qui déjoue la mise en intrigue, cet article fait l'hypothèse d'une extension à la vie quotidienne de ce que le genre du témoignage avait introduit en littérature : une tentative d'objectivation des données de l'expérience personnelle visant à documenter la vie réellement vécue. Les auteur.rice's des œuvres analysées ici consignent et archivent des faits qu'ils attestent afin de les rendre imprescriptibles, contribuant par là même à la remise en cause d'une certaine idée de la littérature dont le champ reste tributaire.

\section{INDEX}

Keywords: non-fiction literature, documentary works, testimony, emplotment, infra-ordinary, literature and archive, Ernaux (Annie), Rolin (Jean)

Mots-clés: littérature de non-fiction, œuvres documentaires, témoignage, mise en intrigue, infra-ordinaire, littérature et archive, Ernaux (Annie), Rolin (Jean)

\section{AUTHORS}

\section{CHARLOTTE LACOSTE}

Université de Lorraine, Crem, F-57000 Metz, France 